\title{
WATER QUALITY ASSESSMENT THROUGH CYTOGENOTOXIC PARAMETERS - A CASE STUDY OF KARAÇOMAK RIVER, TURKEY
}

\author{
Nicoleta Anca Şuțan ${ }^{1}$, Liliana Cristina Soare ${ }^{1 *}$, Ekrem Mutlu $^{2}$, Raluca Dobre ${ }^{1}$, \\ Telat Yanik $^{3}$, Claudiu Şuțan ${ }^{1}$ \\ ${ }^{1}$ Faculty of Science, Physical Education and Informatics, University of Pitesti, Romania. \\ ${ }^{2}$ Faculty of Fisheries, Kastamonu University, Kastamonu, Turkey \\ ${ }^{3}$ Faculty of Fisheries, Atatürk University, Erzurum, Turkey
}

\section{Current Trends in}

Natural Sciences

\begin{abstract}
In the present study, the water quality was determined through cytogenotoxic endpoints by Allium cepa L. assay. Water samples were collected from nine sites selected according to the pollution level and large water discharge points into the Karaçomak River, Turkey. All of the tested water samples had a significant mitodepressive effect on the root tip cells of A. cepa L. They induced a significant increase in chromosomal aberrations like stickiness, anaphase bridges, laggards, and nuclear anomalies, i.e. binucleate cells, giant cells in vitro. It is suggested that the findings of the present study are very important to mitigate the environmental impacts caused by industrial operations on human and ecological health.
\end{abstract}

Keywords: Allium, cytotoxicity, genotoxicity, water quality.

\section{INTRODUCTION}

Clearly one of the fundamental contradictions of the contemporary world is the essentiality of water for sustaining a healthy existence, sufficient food supply and promoting modern technological processes with the long list of pollutants and the signs of water contamination that surround us. Precious water resources become more and more contaminated, water being typically returned to its source in a degraded condition after its use in any of human activities. Estimation of the amount of water pollution is difficult or impossible from municipal wastewater to agricultural, commercial and industrial activities, and nuclear power plant discharges. However, population growth has increased the demand for natural resources that already diminished (Schoonover et al., 2005). Economic development must go on with environmental care and green concerns to give millions of better lives.

A growing number of studies have released long-term hypotheses about the functioning of the environment and the health effects of genotoxins found in water (Ceretti et al., 2016; Singh, 2017). In this sense, the plant test systems may be used as short-term and cost-effective measures in routine water quality monitoring (Bagatini et al., 2009; Leme and Marin-Morales, 2009; Pathiratne et al., 2015, Bonciu et al., 2018). The Allium assay was successfully applied as a bioindicator of environmental pollution (Leme and Marin-Morales, 2009; Pathiratne et al., 2015, Bonciu et al., 
2018). Therefore, cytogenotoxic parameters of $A$. серa L. assay were used for the assessment of the water quality of the Karaçomak River, Turkey in the present study.

\section{MATERIALS AND METHODS}

Area of study

Karaçomak River was originated from the Karaçomak Dam near to the Black Sea coast of Turkey. Karaçomak Dam with a height of $49 \mathrm{~m}$ and 23.1 million $\mathrm{m}^{3}$ a water storage capacity was constructed on Karaçomak River for supplying drinking water of Kastamonu city, for watering the agricultural lands nearby, and for controlling floods from the inflowed little streams in 1973.

Water sampling and preservation

Water samples were collected at nine different stations of Karaçomak River, selected from the pollution points and the points where the entrance of water into the stream was high (Fig. 1). Sampling sites cover the river as follow: $\mathbf{0}^{\text {th }}$ station was located $250 \mathrm{~m}$ away from the floodgates of Karaçomak Dam, $\mathbf{1}^{\text {st }}$ station was located on Stream Çağlayık that provides Karaçomak River with high amount of water and mixes into Karaçomak River at $5^{\text {th }}$ station, $\mathbf{2}^{\text {nd }}$ station was located at the exit of Budamış Village, where the water released from Karaçomak Dam pass through and intense agricultural activities have been performed, $3^{\text {rd }}$ station was located at the point, where the discharge waters were released from the forestry products factory, $4^{\text {th }}$ station was located at the point where the waters released from Karaçomak Dam entered into the city center, $\mathbf{5}^{\text {th }}$ station was located at the Kastamonu city center, where stream Çağlayık and the waters released from Karaçomak Dam combine and then flew as Karaçomak River, $\mathbf{6}^{\text {th }}$ station was located at the point where Karaçomak River leaved Kastamonu city center, $7^{\text {th }}$ station was located at the point where Karaçomak River leaved the car mechanics' region, $\mathbf{8}^{\text {th }}$ station was located at the point where Karaçomak River merged with Brook Daday, outside the Kastamonu city.

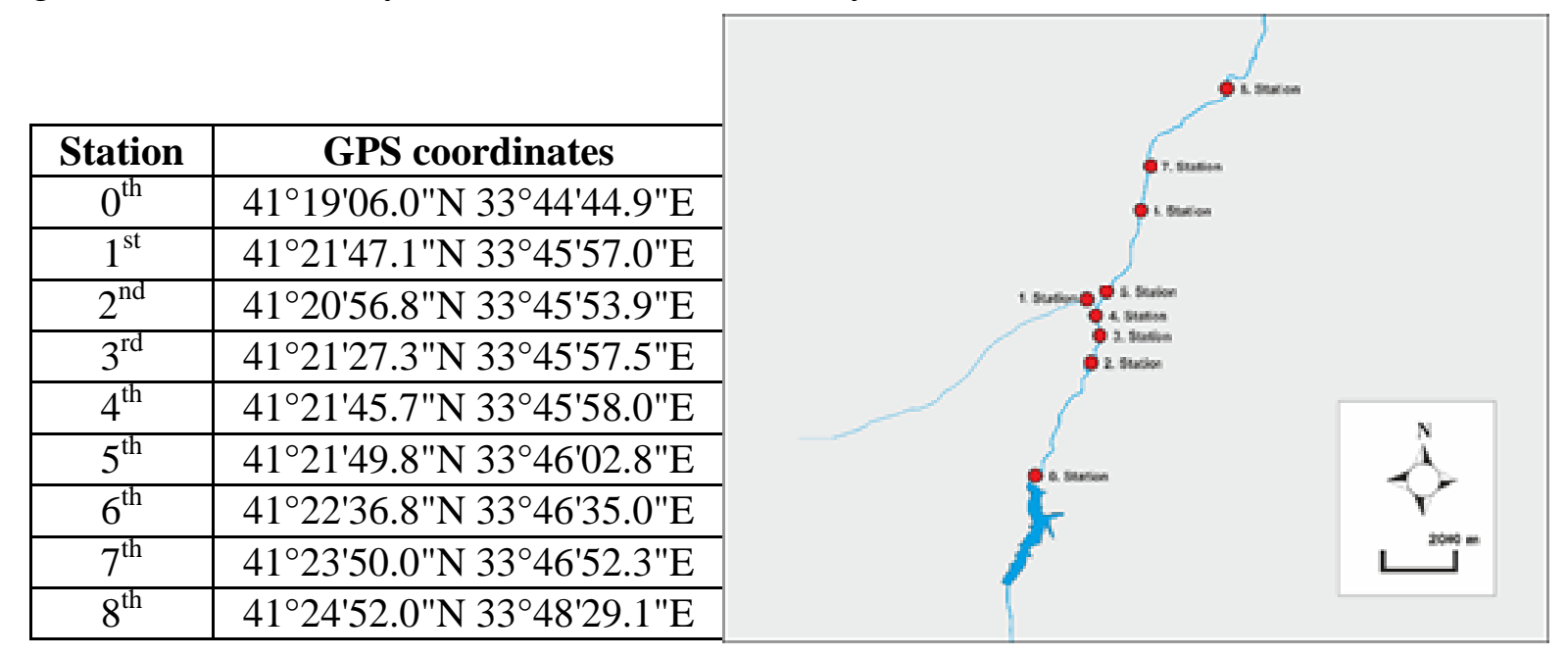

Figure 1. Site sampling location (longitude and latitude of the sampling sites) from Karaçomak River, Turkey

\section{Evaluation of cytogenotoxic potential of water of Karaçomak River}

Allium сера $\mathrm{L}$. test has been used to assess the cytogenotoxic potential of water, taken from stations systematically established along the Karaçomak River. Cytogenotoxic potential of water samples was evaluated by changes in mitotic index (MI) and phase indexes (prophase, metaphase, anaphase, 
telophase), and genotoxicity was measured by calculating the frequency of chromosomal aberrations and nuclear abnormalities induced in root tips cells of $A$. cepa $\mathrm{L}$.

Onion bulbs (A. cepa $\mathrm{L} ., 2 \mathrm{n}=16$ ) from a local variety were approximately the same size and an average weight of about $25 \mathrm{~g}$. The outer scales were carefully removed to expose the root primordia. The bulbs were placed on $30 \mathrm{ml}$ of plastic jars filled with water samples. In our strategy, bulbs were continuously treated with water samples at a specific room temperature $\left(22 \pm 2{ }^{\circ} \mathrm{C}\right)$, until the roots emerged and reached the average length of approx. $2 \mathrm{~cm}$ (Matsumoto et al. 2006). Tap water was used as a control. Originally, the tap water was left open overnight to evaporate the chlorine, which may be responsible for inducing aberrations on A. cepa L. root meristem cells.

After 72 hours of exposure to the water samples, cytogenetic analysis was performed on squash slides prepared as follows: the roots were fixed in a mixture of ethanol (96\%) and glacial acetic acid $(3: 1, v / v)$, for 12 hours at $4^{\circ} \mathrm{C}$, then washed with distilled water and transferred to a watch glass containing $1 \mathrm{~N} \mathrm{HCl}$ for 14 minutes at $60^{\circ} \mathrm{C}$. After hydrolysis, the roots were immersed into the aceto-orcein solution for another 14 minutes at $60^{\circ} \mathrm{C}$. Root tips were randomly selected and cut on glass slides, into a drop of $45 \%$ acetic acid, covered with coverslips, and squashed by a smooth tapping with a matchstick kept upright. For each sample, 3 bulbs were used, from which we have taken around 5 roots for the microscopic analysis.

Mitotic index and determination of aberrations frequency

MI was computed by determining the frequency of cells undergoing mitosis by the total number of cells observed and multiplying the result by 100 (Tedesco and Laughinghouse IV, 2012). The number of cells at various mitosis stages (prophase, metaphase, anaphase, telophase) was calculated as the percentage of the number of dividing cells. The chromosomal and nuclear abnormality was recorded as the percentage of abnormally divided cells in the appropriate mitotic stage. Photomicrographs of cells showing chromosomal and nuclear aberrations, as well as showing normal mitosis, were taken using Olympus CX-31 microscope at 400× magnification.

Statistical analysis

Statistical analyses were performed using the IBM SPSS Statistics 20.0 software package (2011). Results are presented as mean \pm standard error (SE). The data were analyzed for statistical significance using analysis of variance (one-way ANOVA) and Duncan test was used to determine significant differences among means. Significant differences were set at $\mathrm{p}<0.05$.

\section{RESULTS AND DISCUSSIONS}

Mitotic index variation

The results in the variation of the MI are summarized in figure 2. A significant variation in the MI compared with the control was noticed. Rhizogenesis and root growing into the water samples were related to a significant decrease in the number of meristematic cells that have undergone mitosis. The lowest mitotic index was registered when roots have been exposed to the water taken from $3^{\text {th }}$ station. The highest value of the MI, insignificantly different in comparison to the control, was determined for the sample $5^{\text {th }}$ station. This increase may be due to the combination of the stream Çağlayık with the water discharged from the dam Karaçomak flowing as stream Karaçomak. For all other water samples, MI has had intermediate values, but significantly lower compared to the control. The decrease of the MI may be due to a reduction of the ATP level (Jain and Andsorbhoy, 1988, quoted by Pandey et al., 2014) under the pressure of toxic agents presents into the water samples (Şuțan et al., 2016), finally resulting into the inhibition of DNA synthesis (Schneiderman et al., 1971). According to Van't Hof (1968), a reduction in the MI may be due to the blockage of cells 
in the G2 phase of the cell cycle, heading off their entry into mitosis. Moreover, the alteration of the microtubules is closely linked to the reduction of microtubule mitotic activity (Eleftheriou et al., 2012).

In our study, the reduction of MI, especially in the case of cells exposed to water sample 3, can be due to the accumulation of metals in the cell. According to our previous results, in comparison with other samples, the concentrations of metals such as copper, zinc, nickel, lead, mercury and cadmium were high or the highest in the $3^{\text {th }}$ station (Şuțan et al., 2016). According to Qin et al. (2015), excessive accumulation of $\mathrm{Cu}$ in the root cells inhibits the replication of DNA, leading therefore to the cell cycle blockage during the synthesis and the inhibition of the cell proliferation. Hemachandra and Pathiratne (2015) showed that the depression of the mitotic index in the meristematic root cells of $A$. серa $\mathrm{L}$. is exacerbated by the cumulative effect of cadmium mixed with copper. Moreover, nickel can cause irreversible damage to the DNA, knowing that nickel inhibits DNA repair processes. According to De Flora et al. (1990) and Huang et al. (1994) genotoxic effects of the metals were found to be the result of the formation of cross-links DNADNA and DNA-protein and the generation of reactive oxygen species. Apart from the toxic chemical elements identified by an analytical characterization, the waste products can become more hazardous because of the potential that some chemical compounds defined by the lack of genotoxicity can be converted into their genotoxic derivatives (Watanabe and Hirayama, 2001).

Distribution of mitotic phases

An overall statistic interpretation of experimental results revealed a higher and significantly higher number of cells in metaphase and anaphase, characteristic to all tested water samples when compared with the control. Therewith, it must be highlighted the significant reduction in the number of cells in the prophase compared to the control (Fig. 3).

\section{Chromosomal and mitotic abnormalities}

Water samples taken from Karaçomak River induced a statistically insignificant increase in the chromosomal aberrations and mitotic abnormalities, presented in table 1 . The microscopic analysis revealed the presence of the sticky chromosomes, anaphase bridges and laggards within a frequency variable between 1.66 and $4.14 \%$.

A significantly higher frequency of chromosomal aberrations compared to other samples and the control was induced by the water sampled from $3^{\text {th }}$ station. These results support the hypothesis that the observed mutagenicity is due to the contaminants of forestry products from factory discharges. The stress caused by $\mathrm{Cu}$ leads to an increased $\alpha$-tubulin content, which can cause defects in microtubules. The exposure of cells to the very action of $\mathrm{Cu}$ results into the depolymerization of microtubules, their fragmentation and at the end formation of sticky chromosomes (Qin et al., 2015). Also, the $\mathrm{Pb}$ disrupts microtubule organization controls of the cytoskeleton as well as the polymerization of tubules, which delays the disruption of microtubules in the mitosis, leading to a disorder in the spindle.

As a result, aberrant anaphases with chromosomal bridges and sticky chromosomes were noticed (Liu et al., 2009). Rhizogenesis and the stimulation of the roots growth in the tested water samples also induced mitotic aberrations such as nuclear enlargement, binucleate cells, giant cells and ghost cells (Fig. 4).

The cellular damages suggest the possibility of processes of acitokinetic mitosis that results in the formation of binucleate cells. Through the fusion of the interphase nuclei, giant cells with giant nuclei forms there. Giant cells may be polyploid cells that arose by endoreplication (Lee et al., 
Current Trends in Natural Sciences

Vol. 9, Issue 17, pp. 23-30, 2020

https://doi.org/10.47068/ctns.2020.v9i17.003

Current Trends in Natural Sciences (on-line)

ISSN: 2284-953X

ISSN-L: 2284-9521
Current Trends in Natural Sciences (CD-Rom)

ISSN: 2284-9521

ISSN-L: 2284-9521

2009). Endoreplication is associated with the cessation of the cellular division and the start of the cellular differentiation through the development processes of various organs (Veylder et al., 2011). Giant cells are considered as an adaptive response of the biological systems to certain environmental factors (Shang and Wang, 1991). The giant cells can alter the activity of small diploid cells (Barlow, 1985; Demchenko, 1989). According to Geremias et al. (2012) the ability of metals to accumulate in and interact with different locations in the cell wall, plasma membrane and cell nucleus may be activated within the cell for many physiological, biochemical, and molecular effects. These modifications to the cellular membrane may also explain the presence of ghost cells in the present research.

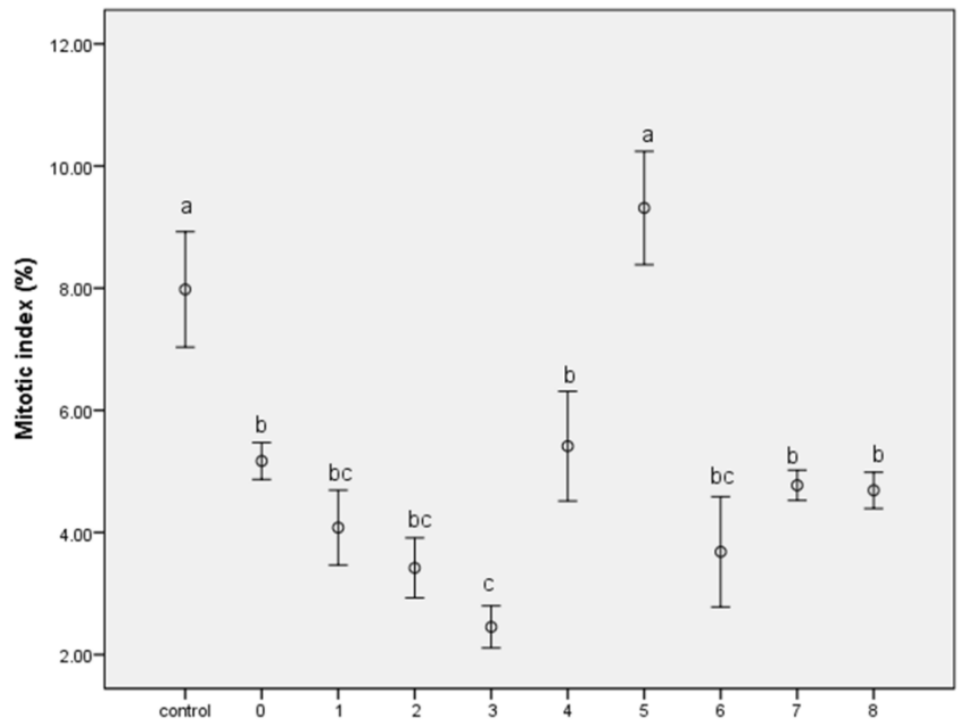

Figure 2. The influence of water samples on the mitotic index of A. cepa L. root meristem cells (a, b, c: the interpretation of the significance of the differences by means of the Duncan test, $p<0.05$ )

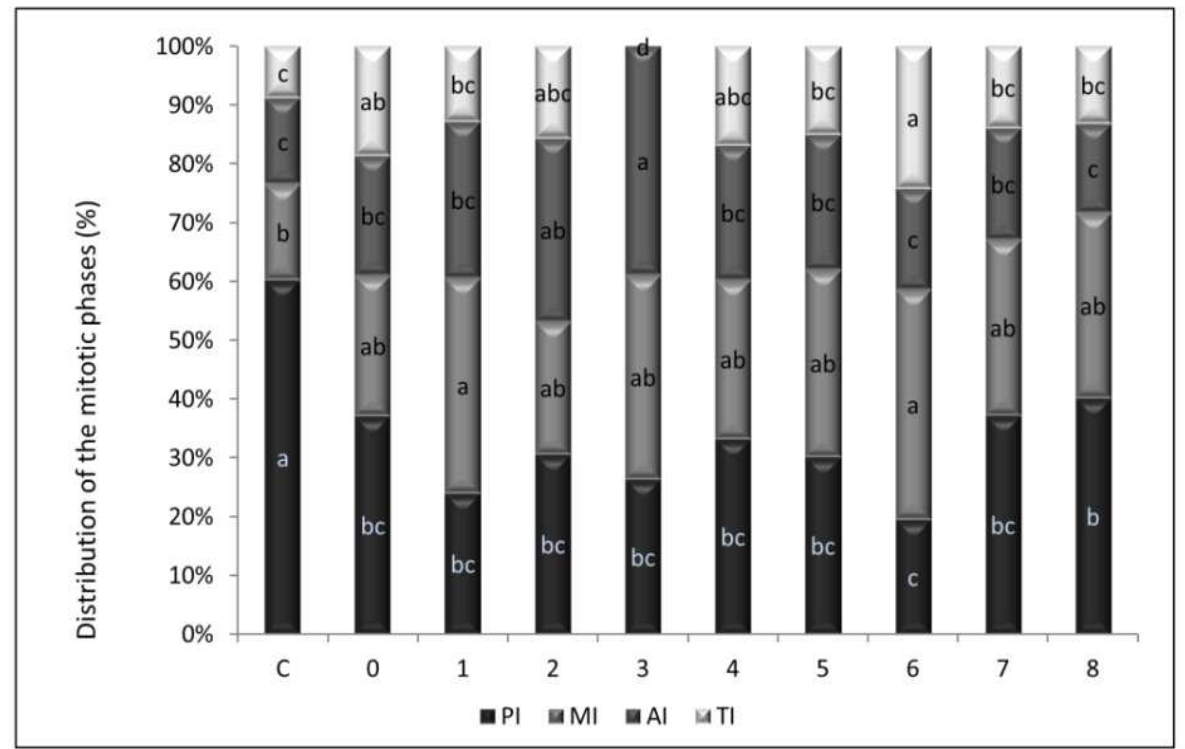

Figure 3. The influence of water samples on the distribution of the mitosis phases on A. cepa L. root meristem cells ( $a, b, c$ : interpretation of the significance of the differences, by means of the Duncan test, $p<0,05$ ) 


\section{Current Trends in Natural Sciences}

Vol. 9, Issue 17, pp. 23-30, 2020

https://doi.org/10.47068/ctns.2020.v9i17.003

Current Trends in Natural Sciences (on-line)

ISSN: 2284-953X

Current Trends in Natural Sciences (CD-Rom)

ISSN: 2284-9521

ISSN-L: 2284-9521

ISSN-L: 2284-9521

Of all water samples tested, $6^{\text {th }}, 7^{\text {th }}$, and $8^{\text {th }}$ samples have been pinpointed for the presence of ghost cells with varying frequency (Fig. 4). The ghost cells were first described in humans (dyskeratotic cells) as similar cells to viable cells, but with a distinct outline (Highman and Ogden, 1944). According to Levy (1973), the ghost cells are an indicator of the cellular death caused by the local anoxia. In our study, the lowest dissolved oxygen value was determined for the water sample 7 , along with the highest $\mathrm{pH}$ and highest temperature (Şuțan et al., 2016), configuring conditions of the reducing oxygen intake. For the same water samples, cytotoxicity was manifested through the damage of the cellular membrane either (Fig. 4). It is conceivable that by crossing the Kastamonu city, and a region of intense auto mechanics, in the Karaçomak River there are accumulated debris with high cytotoxic potential.

Cytotoxicity of chemical agents may generate a complex sequence of events that can eventually end with cellular death (Kaioumova et al., 2001). A high frequency of cells with characteristics of cells under the cellular death process was noticed by Hoshina and Marin-Morales (2009) in meristematic cells of A. cepa L. exposed to waters with contaminants derived from the petroleum refinery. With a low frequency, we observed the meristematic root cells under necrosis and sometimes a smooth tendency to expel the nucleus (Fig. 4). Necrosis may be spontaneous or triggered by oxidative stress, infectious agents, toxic chemical compounds, or hypersensitivity (Zakeri and Lockshin, 2002). During necrosis, the cell first swells itself then the plasma membrane bursts, leading to cell lysis (Majno and Joris, 1995).

In the current study, the testing of the water collected from the Karaçomak River showed high cytotoxicity over the root tip cells of $A$. cepa $\mathrm{L}$., the substances and chemical complexes altering the physiological processes and interfering with cells viability. Therefore, it is concluded that the results obtained in this study are of great relevance for the environmental contamination and damages generated by industrial activities.

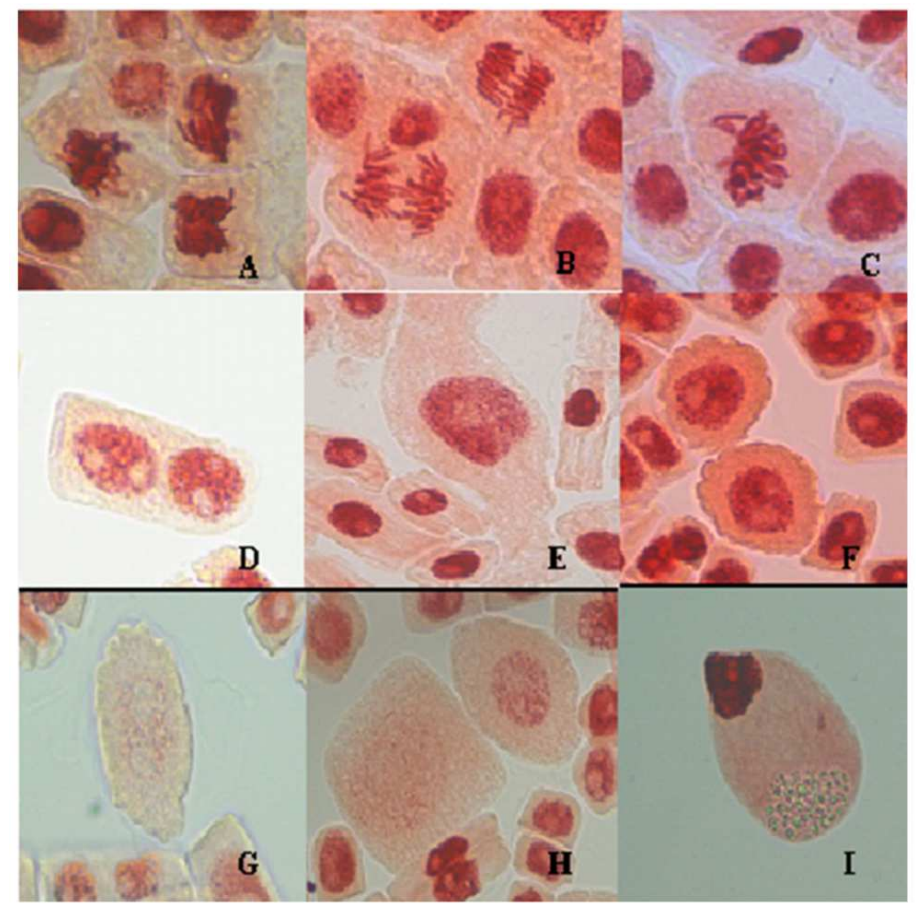

Figure 4. Chromosomal aberrations and nuclear abnormalities in A. cepa L. root tip cells: (A) sticky metaphase and anaphase; (B) anaphase bridges; (C) laggard chromosomes; (D) binucleated cell; $(E)$ giant cell; $(F)$ plasma membrane deterioration; $(G, H)$ ghost cell; $(I)$ cellular necrosis and nuclear extrusion proneness 
Table 1. Citogenetic analysis of A. cepa L. root tips exposed to water samples collected from Karaçomak River, Turkey

\begin{tabular}{|c|c|c|c|c|c|c|c|c|c|}
\hline \multirow{2}{*}{ Assay } & \multicolumn{4}{|c|}{ Chromosomal aberrations } & & \multicolumn{4}{|c|}{ Nuclear abnormalities } \\
\hline & Stickiness & $\begin{array}{c}\text { Anaphase } \\
\text { bridges }\end{array}$ & Laggards & Total \% & $\begin{array}{c}\text { Nuclear } \\
\text { enlargement }\end{array}$ & $\begin{array}{c}\text { Binucleate } \\
\text { cells }\end{array}$ & Giant cells & Ghost cells & Total \% \\
\hline Control & $0 \mathrm{~b}$ & $0 \mathrm{~b}$ & $0.68 \pm 0.02 b$ & $0 \mathbf{a}$ & $0 \mathrm{~g}$ & $0 \mathrm{~g}$ & $0 \mathrm{~g}$ & $0 \mathrm{~g}$ & $\mathbf{0} \mathbf{a}$ \\
\hline $0^{\text {th }}$ site & $6.66 \pm 2.08 \mathrm{a}$ & $3.03 \pm 3.03 \mathrm{ab}$ & $0 \mathrm{~b}$ & $3.23 \pm 1.92 \mathrm{a}$ & $12.40 \pm 2.97 \mathrm{de}$ & $0.30 \pm 0.15 \mathrm{~g}$ & $0.24 \pm 0.19 \mathrm{~g}$ & $0 \mathrm{~g}$ & $3.23 \pm 3.05 a$ \\
\hline $1^{\text {st }}$ site & $3.70 \pm 3.70 \mathrm{ab}$ & $2.30 \pm 2.30 \mathrm{ab}$ & $1.11 \pm 1.11 \mathrm{ab}$ & $2.37 \pm 0.74 a$ & $19.83 \pm 3.36 \mathrm{bc}$ & $0.30 \pm 0.17 \mathrm{~g}$ & $0.40 \pm 0.24 \mathrm{~g}$ & $0 \mathrm{~g}$ & $5.13 \pm 4.89 \mathrm{a}$ \\
\hline $2^{\text {nd }}$ site & $3.31 \pm 0.44 \mathrm{ab}$ & $1.00 \pm 1.00 \mathrm{ab}$ & $2.08 \pm 2.08 \mathrm{ab}$ & $2.13 \pm 0.66 a$ & $27.68 \pm 2.26 \mathrm{a}$ & $1.31 \pm 0.26 \mathrm{~g}$ & $0.44 \pm 0.44 \mathrm{~g}$ & $0 \mathrm{~g}$ & $7.35 \pm 6.77 a$ \\
\hline $3^{\text {rd }}$ site & $7.11 \pm 0.37 \mathrm{a}$ & $3.25 \pm 1.80 \mathrm{ab}$ & $2.08 \pm 2.08 \mathrm{ab}$ & $4.14 \pm 1.51 a$ & $25.39 \pm 6.40 \mathrm{ab}$ & $0.52 \pm 0.09 \mathrm{~g}$ & $0.58 \pm 0.29 \mathrm{~g}$ & $0 \mathrm{~g}$ & $6.62 \pm 6.25 a$ \\
\hline $4^{\text {th }}$ site & $3.89 \pm 0.18 \mathrm{ab}$ & $3.12 \pm 1.93 \mathrm{ab}$ & $0.9 \pm 0.9 \mathrm{ab}$ & $2.63 \pm 0.89 a$ & $17.58 \pm 2.96 \mathrm{~cd}$ & $0.92 \pm 0.21 \mathrm{~g}$ & $0.70 \pm 0.52 \mathrm{~g}$ & $0 \mathrm{~g}$ & $4.8 \pm 4.26 \mathrm{a}$ \\
\hline $5^{\text {th }}$ site & $3.82 \pm 2.56 \mathrm{ab}$ & $1.58 \pm 1.58 \mathrm{ab}$ & $0 \mathrm{~b}$ & $1.80 \pm 1.10 \mathrm{a}$ & $27.76 \pm 5.92 \mathrm{a}$ & $0.84 \pm 0.30 \mathrm{~g}$ & $6.67 \pm 1.95 \mathrm{efg}$ & $0 \mathrm{~g}$ & $8.81 \pm 6.48 \mathrm{a}$ \\
\hline $6^{\text {th }}$ site & $7.22 \pm 3.62 \mathrm{a}$ & $1.06 \pm 1.06 \mathrm{ab}$ & $0 \mathrm{~b}$ & $2.76 \pm 2.25 a$ & $10.22 \pm 2.26 \mathrm{ef}$ & $0.57 \pm 0.28 \mathrm{~g}$ & $5.46 \pm 3.03 \mathrm{fg}$ & $0.31 \pm 0.27 \mathrm{~g}$ & $4.14 \pm 2.34 a$ \\
\hline $7^{\text {th }}$ site & $5.65 \pm 1.28 \mathrm{ab}$ & $3.33 \pm 3.33 \mathrm{ab}$ & $0 \mathrm{~b}$ & $2.99 \pm 1.63 a$ & $21.37 \pm 1.65 b c$ & $0.25 \pm 0.06 \mathrm{~g}$ & $2.08 \pm 2.08 \mathrm{~g}$ & $0.27 \pm 0.18 \mathrm{~g}$ & $5.99 \pm 5.14 a$ \\
\hline $8^{\text {th }}$ site & $3.19 \pm 2.21 \mathrm{ab}$ & $1.80 \pm 1.80 \mathrm{ab}$ & $0 \mathrm{~b}$ & $1.66 \pm 0.92 a$ & $17.58 \pm 2.67 \mathrm{~cd}$ & $0.75 \pm 0.09 \mathrm{~g}$ & $0 \mathrm{~g}$ & $1.10 \pm 0.25 \mathrm{~g}$ & $4.8 \pm 4.24 a$ \\
\hline
\end{tabular}

*each value represents the mean $\pm(\mathrm{SE})$ for each experimental variant. Means with the same latter exponent do not differ significantly at the level of $\mathrm{p}<0.05$ by the Duncan test

\section{CONCLUSIONS}

The development of industries along the Karaçomak River suggests a negative impact on water quality. Wood composites factory and auto-mechanic activities induced the largest variation of cytogenotoxic endpoints. Taking into account all the forms of cell changes mentioned herein, we conclude that the water samples examined were cytogenotoxic to the A. cepa L. test-organism based on statistically significant mitotic division inhibition, elevated chromosomal aberration frequency and nuclear defects that can cause cell death. This study increases the concerns about the present state of the rivers and intends to assist in mitigating the environmental impacts of human activities.

\section{REFERENCES}

Bagatini, M.D., Vasconcelos, T.G., Laughinghouse IV, H.D. Martins, A.F. \& Tedesco, S.B. (2009). Biomonitoring hospital effluents byAllium cepa L. test. Bull Environ Contam Toxicol, 82, 590-592.

Barlow, P.W. (1985). The nuclear endoreduplication cycle in metaxylem cells of primary roots of Zea mays L. Ann Bot, 55, 445-457.

Bonciu, E., Firbas, P., Fontanetti, C.S., Wusheng, J., Karaismailoğlu, M.C., Liu, D., Menicucci, F., Pesnya, D.S., Popescu, A., Romanovsky, A.V., Schiff, S., Ślusarczyk, J., de Souza, C.P., Srivastava, A., Sutan A., Papini, A. (2018). An evaluation for the standardization of the Allium cepa test as cytotoxicity and genotoxicity assay. Caryologia, 71(3), 191-209.

Ceretti, E., Moretti, M., Zerbini, I., Villarini, M., Zani, C., Monarca, S., Feretti, D. (2016). Occurrence and control of genotoxins in drinking water: a monitoring proposal. J Public Health Res. 5(3), 769.

De Flora, S., Bagnasco, M., Serra, D., Zanacchi, P. (1990). Genotoxicity of chromium compounds. A review. Mutat Res, 238, 99-172.

Demchenko, N.P., (1989). Changes in DNA content in the cells of phloem complex of the wheat root during their development. Tsitologiya, 31, 664-676.

De Veylder, L., Larkin, J.C., Schnittger, A. (2011). Molecular control and function of endoreplication in development and physiology. Trends Plant Sci, 16, 624-634.

Eleftheriou, E.P., Adamakis, I.D.S., Melissa, P. (2012). Effects of hexavalent chromium on microtubule organization, ER distribution and callose deposition in root tip cells of Allium cepa L. Protoplasma, 249, 401-416. 


\section{Current Trends in Natural Sciences}

Vol. 9, Issue 17, pp. 23-30, 2020

https://doi.org/10.47068/ctns.2020.v9i17.003

Current Trends in Natural Sciences (on-line)

ISSN: 2284-953X

Current Trends in Natural Sciences (CD-Rom)

ISSN: 2284-9521

ISSN-L: 2284-9521

ISSN-L: 2284-9521

Geremias, R., Bortolotto, T., Wilhelm-Filho, D., Pedrosa, R.C., De Fávere, V.T. (2012). Efficacy assessment of acid mine drainage treatment with coal mining waste using Allium cepa L. as a bioindicator. Ecotoxicol Environ Saf, 79, 116-121.

Hemachandra, C.K., Pathiratne, A. (2015). Assessing toxicity of copper, cadmium and chromium levels relevant to discharge limits of industrial effluents into inland surface waters using common onion, Allium cepa bioassay. Bull Environ Contam Toxicol, 94, 199-203.

Highman, B., Ogden, G.E. (1944). Calcified epithelioma. Arch Pathol, 37, 169-174.

Hoshina, M.M., Marin-Morales, M.A. (2009). Micronucleus and chromosome aberrations induced in onion (Allium сера) by a petroleum refinery effluent and by river water that receives this effluent. Ecotoxicol Environ Saf, 72, 2090-2095.

Huang, X., Zhuang, Z., Frenkel, K., Costa, M., Klein, C.B. (1994). The role of nickel and nickel-mediated reactive oxygen species in the mechanism of nickel carcinogenesis. Environ Health Perspect, 102, 281-284.

IBM Corp. Released (2011). IBM SPSS Statistics for Windows, Version 20.0. Armonk, NY: IBM Corp.

Jain, A.K., Andsorbhoy, R.K. (1988). Cytogenetical studies on the effects of some pesticides III. Concluding remarks. Cytologia, 53, 427-436.

Kaioumova, D., Süsal, C., Opelz, G. (2001). Induction of apoptosis in human lymphocytes by the herbicide 2,4dichlorophenoxyacetic acid. Hum Immunol, 62, 64-74.

Lee, H.O., Davidson, J.M., Duronio, R.J. (2009). Endoreplication: Polyploidy with purpose. Genes Dev, 23, $2461-2477$.

Leme, D.M., Marin-Morales, M.A. (2009). Allium cepa test in environmental monitoring: A review on its application. Mutat Res, 682, 71-81.

Levy, B.A. (1973). Ghost cells and odontomas. Oral Surg Oral Med Oral Pathol Oral Radiol Endod, 36, 851-855.

Liu, D., Xue, P., Meng, Q., Zou, J., Gu, J., Jiang, W. (2009). Pb/Cu effects on the organization of microtubule cytoskeleton in interphase and mitotic cells of Allium sativum L. Plant Cell Rep, 28, 695-702.

Majno, G., Joris, I. (1995). Apoptosis, oncosis, and necrosis: an overview of cell death. Am J Pathol, 146, 3-15.

Matsumoto, S.T., Mantovani, M.S., Malagutti, M.I.A., Dias, A.U., Fonseca, I.C., Marin-Morales, M.A. (2006). Genotoxicity and mutagenicity of water contaminated with tannery effluents, as evaluated by the micronucleus test and comet assay using the fish Oreochromis niloticus and chromosome aberrations in onion root-tips. Genet Mol Biol, 29, 148-158.

Pandey, H., Kumar, V., Roy, B.K. (2014). Assessment of genotoxicity of some common food preservatives using Allium cepa L., as a test plant. Toxicol Rep, 1, 300-308.

Pathiratne, A., Hemachandra, C.K., De Silva, N. (2015). Efficacy of Allium cepa test system for screening cytotoxicity and genotoxicity of industrial effluents originated from different industrial activities. Environ Monit Assess, 187(12), 730.

Qin, R., Wang, C., Chen, D., Björn, L.O., Li, S. (2015). Copper-induced root growth inhibition of Allium cepa var. agrogarium L. involves disturbance in cell division and DNA damage. Environ Toxicol Chem, 34, 1045-1055.

Shang, X.M., Wang, W.C. (1991). DNA amplifications, chromatin variations, and polytene chromosomes in differentiating cell of common bread wheat in vitro and root of regenerated plants in vivo. Genome, 34, 799-809.

Schneiderman, M.H., Dewey, W.C., Highfield, D.P. (1971). Inhibition of DNA synthesis in synchronized Chinese hamster cell treated in G1 with cycloheximide. Exp Cell Res, 67, 147-155.

Schoonover, J.E., Lockaby, B.G., Pan, S. (2005). Changes in chemical and physical properties of stream water across an urban-rural gradient in western Georgia. Urban Ecosyst, 8, 107-124.

Singh, V.P. (2017). Challenges in meeting water security and resilience. Water Int, 42, 349-359.

Şuțan, N.A., Mutlu, E., Yanik, T., Dobre, R. (2016). A short report regarding the physicochemical properties of surface water quality in Karaçomak stream, Turkey. AIP Conf. Proc, 1726, International Conference on Advances in Natural and Applied Sciences, 21-23.04.2016, Antalya, Turkey.

Tedesco, S.B., Laughinghouse, IV H.D. (2012). Bioindicator of genotoxicity: the Allium cepa test. In: Environmental Contamination, Srivastava JK (Ed), InTech Publisher, Rijeka, pp. 137-156.

Van't Hof, J. (1968). The action of IAA and kinetin on the mitotic cycle of proliferative and stationary phase excised root meristem. Exp Cell Res, 51, 167-176.

Watanabe, T., Hirayama, T. (2001). Genotoxicity of soil. J Health Sci, 47, 433-438.

Zakeri, Z., Lockshin, R.A. (2002). Cell death during development. J Immunol Methods, 265, 3-20. 